\title{
National Chain Restaurant Practices Supporting Food Sustainability
}

\section{Authors: Courtney A. Pinard, Carmen Byker, Elena Serrano, and Alison H. Harmon}

This is an Accepted Manuscript of an article published in Journal of Hunger \& Environmental Nutrition on October 2, 2014, available online: http://www.tandfonline.com/10.1080/19320248.2014.898169.

Pinard, Courtney A., Carmen Byker, Elena Serrano, and Alison H. Harmon. "National Chain Restaurant Practices Supporting Food Sustainability." Journal of Hunger \& Environmental Nutrition 9, no. 4 (October 2, 2014): 535-545. doi:10.1080/19320248.2014.898169. 


\title{
National Chain Restaurant Practices Supporting Food Sustainability
}

\begin{abstract}
Although sustainable foods are becoming popular among consumers, there is little known about restaurants' practices, such as sourcing local or organic products. The goal of this study was to examine published information about sustainable practices in chain restaurants in 2008 and 2011. Restaurant websites were inspected in 2008 and 2011/2012 for information supporting sustainable food practices. Sustainability ratings were categorized as no practice, planned practice, or practice. In 2008, there were few reported practices, however in 2011 there was a proliferation. This research demonstrates the increasing popularity of sustainable food practices and the potential to reach a broader audience.
\end{abstract}

Keywords: sustainable, food, restaurant, policy, practice, diffusions of innovations 


\title{
National Chain Restaurant Practices Supporting Food Sustainability
}

\author{
Courtney A. Pinard ${ }^{\mathrm{a}}$, Carmen Byker $^{\mathrm{b}}$, Alison Harmon ${ }^{\mathrm{c}}$, Elena Serrano $^{\mathrm{d}}$
}

${ }^{a}$ Gretchen Swanson Center for Nutrition, Omaha, NE 68105, USA, cpinard@,centerfornutrition.org, Ph: 1-402-559-5575, Fax: 1-402-559-7302.

${ }^{b}$ Montana State University, Department of Health and Human Development, Romney Gym, Bozeman, MT 59717, USA, carmen.byker@montana.edu, Ph: 1-406-994-1952, Fax: 1-406-9946314.

'Montana State University, Department of Health and Human Development, Romney Gym, Bozeman, MT 59717, USA, harmon@montana.edu, Ph: 1-406-994-6338, Fax: 1-406-994-6314.

${ }^{\mathrm{d}}$ Virginia Tech, Department of Human Nutrition, Foods and Exercise, 201 Wallace Annex, Blacksburg, VA 24061, USA, serrano@vt.edu, Ph: 1-540-231-3464, Fax: 540-231-7576.

\section{Corresponding Author:}

Courtney A. Pinard

Gretchen Swanson Center for Nutrition, Omaha, NE 68105, USA,

cpinard@centerfornutrition.org, Ph: 1-402-559-5575, Fax: 1-402-559-7302

\begin{abstract}
Although sustainable foods are becoming popular among consumers, there is little known about restaurants' practices, such as sourcing local or organic products. The goal of this study was to examine published information about sustainable practices in chain restaurants in 2008 and 2011. Restaurant websites were inspected in 2008 and 2011/2012 for information supporting sustainable food practices. Sustainability ratings were categorized as no practice, planned practice, or practice. In 2008, there were few reported practices, however in 2011 there was a proliferation. This research demonstrates the increasing popularity of sustainable food practices and the potential to reach a broader audience.
\end{abstract}

Keywords: sustainable, food, restaurant, policy, practice, diffusions of innovations 


\section{Introduction}

There is growing awareness and attention on sustainable foods, largely driven by consumer interest and demand. ${ }^{1,2}$ The rising trend has resulted in the exponential growth of "farm to where you are" programs (also known as direct marketing), including farmers markets, community supported agriculture, farm to institution, and small farms. ${ }^{3,4}$ The topic is also infiltrating popular media and books. ${ }^{5,6}$ Finally, sustainable practices are becoming increasingly adopted by institutions such as hospitals and higher education institutes and becoming the center of advocacy efforts. ${ }^{7}$ The United States Department of Agriculture defines sustainability as it relates to food as satisfying human food and fiber needs; enhance environmental quality and the natural resource base upon which the agricultural economy depends; make the most efficient use of nonrenewable resources and on-farm resources and integrate, where appropriate, natural biological cycles and controls; sustain the economic viability of farm operations; and enhance the quality of life for farmers and society as a whole. ${ }^{8}$

Although these mark significant shifts in the food system, there are few studies examining how sustainability trends may be influencing restaurants' practices, despite the fact that six out of the top 20 trends forecasted by the National Restaurant Association for 2012 focus on sustainability, with four specifically using the word local (i.e., locally sourced meats and seafood, locally grown produce, hyper-local sourcing as in restaurant gardens, and locally-produced wine and beer. ${ }^{9}$ Changes in restaurant practices are significant responses to consumer demand because nearly half of all food expenditures and over one-third of calories consumed by Americans are also

prepared away from home. ${ }^{10}$ Focusing on sustainable food practices in restaurants that improve 
the health of the people, land, and food, ${ }^{11}$ has the potential to reach a broader population not served by smaller food outlets, possibly resulting in improved dietary and health outcomes. ${ }^{12}$

The aim of this study is to compare and contrast published practices and/or planned practices of the top 20 American chain restaurants (by sales) in 2008 and in 2011 to characterize sustainability trends driven by consumer demand within the restaurant industry.

\section{Methods}

\section{Inclusion Criteria}

The top 20 American chain restaurant data was obtained from the Nation's Restaurant News' (NRN) 2008 and 2011 publications entitled “Top 100," which explores chain restaurant

performance by sales. ${ }^{13,14}$ NRN defines a "chain restaurant" as a business with multi-units, a brand, trademark and/or logo. Each chain restaurant is then separated by concept (i.e., sandwich, coffee, contract, pizza, chicken, beverage-snack, casual dining, family, bakery-café, convenience store and hotel). For the purpose of this study, only the top 20 restaurants that served meals were included, as they are classified as a restaurant, thus excluding two non-restaurant food outlets.

\section{Data Acquisition}

First, websites of the top 202008 and 2011 American chain restaurants were examined for press releases, promotional materials, and/or handbooks suggesting sustainable food products, and 
practices. The initial search was conducted in 2008 and a follow-up search in 2011. It was anticipated that the restaurants would market their efforts and sustainable food practices, making a search and evaluation of published materials appropriate. Following this initial search, more information was found through a search engine (Google) by typing in the restaurant's name and a separate search with the following keywords: farmer, producer, traceable, food supply chain, food safety, local food, United States, sustainable, natural, seasonality, organic, cage-free, nonconfined, antibiotic or hormone free, sustainable fish, animal welfare approved, fair trade, nutrition labeling, diversion, and "non-profit pay what you want". Search terms were created by reviewing literature about restaurant sustainability using the Shades of Green Checklist as a guide. ${ }^{11}$ Sustainable food practices were defined as those things that the restaurant has direct control over (e.g., choice of procurement of foods) and are related to food (e.g., excluding things like packing). Other sustainable food practices related to the environmental impact of the building design and packaging were not within the scope of this analysis.

\section{Data Analysis}

The restaurant's sustainable food practices rating fell into the following categories: a planned practice; an official practice; or no practice or planned practice. Two coders were used for each restaurant's website and other documents. A planned practice included a plan for a sustainable food practice, without implementation of the plan. An official sustainable food practice indicates that the chain restaurant implements one or more sustainable food actions, regardless of the scale of the action. Follow-up emails and calls were made as doubts or questions arose. 


\section{Results}

The top 20 restaurants in 2011 are shown in Table 1 in order of sales. McDonald's had the largest sales while IHOP had the lowest sales (2008 practices or planned practices are noted in italics, while 2011 practices or planned practices are not italicized). The top restaurant chains ranked by sales were the same in 2008 and 2011, with the following exception: Outback Steakhouse and Red Lobster are both in the top 20 restaurants in 2008 but not in 2011, and Panera and IHOP are in the top 20 restaurants in 2011 but were not in 2008.

As shown in italics in Table 1, in 2008, few specific practices or planned practices were found in any of the top 20 American chain restaurant websites and promotional material. The number of practices in 2008 totaled three and focused on animal products. Burger King supplied a small percentage of cage-free eggs from their supplier, Subway sourced only $100 \%$ hormone-free milk, and Red Lobster ensured no over-fished species. McDonald's, Starbucks, Taco Bell, Pizza Hut, and KFC all provided the beginning steps to traceable food supply chains in documents that explore sustainability. Burger King and Wendy's suggested animal welfare for pork and egg sourcing, but no specific practices were implemented.

In 2011, practices and planned practices proliferated. There were 20 practices and 12 planned practices noted across the top 20 restaurants in America. Some of these practices included Subway demonstrating a commitment to buy produce from the United States as well as providing nutrition labeling for some of their sandwiches on drink containers and napkins. Other examples include Starbucks serving fair trade coffee raised sustainably and a few restaurants (e.g., Burger 
King, Wendy's, Sonic) serving some cage free eggs. Some of the restaurants that have the highest sales also have more policies and planned practices for sustainable food practices (e.g., McDonalds $=3$ policies, 4 planned practices). Panera bread is the exception to this as it is $17^{\text {th }}$ in terms of sales, yet demonstrates a commitment to sustainable food practices ( 3 policies, 1 planned practice). Some terms entered into the search did not yield any restaurant practices or planned practices - these included: free-range, grass fed, composting, fair wages and labor policies for farmers, not artificial ingredients/additives, food cooperatives or other aggregation methods such as a food hub, seasonality (i.e., eating foods that are in season), and claims on sugars or calories aligning with the Food and Drug Administration (FDA).

\section{Discussion}

This study demonstrates the shift towards a more sustainable food system for diverse audiences. Recent public interest surrounding the benefits of sustainable foods have created an exponential growth of "farm to where you are" programs including, farmers markets, community supported agriculture, farm to institution, and small farms. ${ }^{3}$ The proliferation of farmers markets in recent years demonstrates increasing interest in more sustainable food systems. For example, farmers markets show immense growth from 1,755 in 1994, to 7,864 in 2012. ${ }^{4}$ However, it has been noted, that the typical clientele at farmers markets are middle-aged females who lived within proximal distance of the market. ${ }^{12}$ Low-income and racially/ethnically diverse populations tend to frequent more fast food options, such as the chain restaurants focused on in the current study. ${ }^{15-17}$ The promotion of direct to consumer outlets to diverse audiences is critical, therefore, capturing the sustainable efforts in chain restaurants is important from a nutrition perspective. 
The restaurants that were reviewed for the current study are arguably accessible for a diverse audience. In 2008, the top 20 American chain restaurants have listed few sustainable food practices or planned practices posted online. Of note, a number of these restaurants were beginning to make decisions in response to corporate social responsibility policies and/or consumer marketing initiatives and demand, which resulted in various sustainable food practices being planned for the future. In 2011 there was an increase in the number of practices and planned practices described by the top 20 chain restaurants.

Certain areas of sustainable food practices were more prevalent than others, which the authors suggest is perhaps a function of the public demand and ease of implementation. Rogers Diffusion of Innovation framework supports this notion, that certain features of a practice make it more or less likely to be adopted including: relative advantage (how improved an innovation is over the previous generation), compatibility (the level of compatibility that an innovation has to be assimilated into an individual's life), complexity or simplicity (if the innovation is perceived as complicated or difficult to use, an individual is unlikely to adopt it), trialability (how easily an innovation may be experimented), and observability (the extent that an innovation is visible to others, with greater visibility increasing rates of adoption). ${ }^{18}$

Many of the planned practices that the top 20 restaurants in America described indicate the early stages of adoption, and ultimately, perhaps those planned practices that result in practices that are implemented have features with Rogerian characteristics described above that make them more likely to be adopted. For example, a few of the restaurants describe that a certain small 
percentage of their eggs $(2-5 \%)$ are cage free. This small percentage allows the restaurant to communicate their sustainability (observability) to customers, perhaps while trialing this practice that may have relative advantage (healthier chickens, more nutritious eggs), and is compatible with their organization (cost, preparation methods). On the other hand, some of the search terms that did not yield any restaurant official practices or planned practices (e.g., free-range, composting, seasonality) are perhaps lower in the qualities that Roger's defines as increasing adoption rates (relative advantage, compatibility, complexity or simplicity, trialability, and observability) and are practices that may only be considered in the future once some of the “easier" sustainable food practices are implemented. ${ }^{18}$

The increase in sustainable food practices may be attributed to the growing awareness and demand from the consumer. The average consumer is becoming increasingly aware of where their food is coming from. ${ }^{19}$ In addition, the top trends suggested by the NRA for 2012 include many examples of sustainable food practices: locally sourced meats and seafood, organic produce, sustainability, and others. ${ }^{9}$ This shift may be an important step to set precedence for other large restaurants and grocery stores, already Wal-Mart and Costco have switched to cage free eggs for their store brand.

An example of a restaurant capitalizing on a segment of the market that values sustainable food practices is Chipotle Mexican Grill, number 55 out of the "Top 100 Chains Ranked by US Systemwide Foodservice Sales" in 2008 and 36 in 2011. ${ }^{13,14}$ Chipotle follows a strict "Food with Integrity" policy, whereby all food is sourced with the most integrity possible - whether that means local, organic, or by other sustainably sourced means. ${ }^{20}$ Although sustainable food 
sourcing may not be the easiest method, it is proven to be of interest to consumers as it is in line with the "green" industry. This value may make alternative restaurant practices potentially profitable. It is suspected that many restaurants will follow suit in the years to come. One example of a trend that some restaurants have implemented is the reduction in portion sizes, which is to reduce energy intake and ultimately beneficial for weight management and nutrition. $^{21}$

Other examples come from Europe, where sustainable food practices are well in advance of the changes occurring in America. Some of these American-owned chains also have locations worldwide, and are obligated to conform to higher European standards. For example, McDonalds sells only organic milk in its British restaurants. ${ }^{22}$ A more anecdotal account from author CB when visiting Spain, “Our typically brown McDonald's tray came with a sheet of paper that advertised the purity (in terms of production process) and freshness of their meat and vegetables. Additionally, several pamphlets were available for customers to read about the nutritional content of food and where it comes from". The website for McDonald's Spain website supports this anecdote by describing several sustainable food practices including a national supply chain and sustainably sourced coffee and fish, and higher standards of animal welfare. ${ }^{23}$

As the sustainable foods movement continues to grow, it is important to both maintain awareness of who is being served - to ensure equitable access to an improved food system to promote better nutrition. It is also critical to hold large businesses accountable for the practices they describe in their marketing materials. Given the rise in interest in sustainable foods, corporate social responsibility no longer has to pit 'society' against 'business' as these efforts become more 
economically profitable. ${ }^{24}$ Many instances of restaurants' communication to the public about sustainable food practices contain vague statements and descriptions, which may or may not amount to much action or change. In order to hold restaurants and corporations accountable, third party certifications like organic can help, but public awareness about greenwashing will also have a place in this discussion. ${ }^{25}$

There are a few limitations to this study. First, restaurants may have sustainable food planned or official practices that are not posted. Although possible, it seems that restaurants would advertise sustainable efforts, as it may be beneficial to business in a culture where consumers are demanding sustainability. The purpose of this study was to identify efforts seen through the lens of a consumer. Additionally, the top 20 restaurant chains were analyzed by sales and not by fastest growth. This being true, still highest sales represent where the greatest portion of consumer money is spent. Lastly, sustainable food may always be difficult to source for restaurants given the lack of standardization and seasonality of food. For example, organically produced foods may be too costly to procure at the volume necessary with current budgets. On the other hand, producers may not have the volume of product needed to source such large quantities of sustainable foods. Given the shift towards more sustainably produced foods in restaurants, it will also be important to consider the agriculture supply and whether sufficient product is available to meet this increasing demand. Finally, the current study focused on the aspects of restaurant operations that included food. However, many of the chain restaurants described sustainable practices that involved their building, equipment, and packaging. Future research may want to incorporate these "non-food" aspects. 
The findings from this study demonstrate the movement toward a more sustainable food system. In 2008, the sustainable food trend was beginning but was still a fringe movement, the recent advances in the top 20 restaurants in America demonstrates that sustainable food, and the demand from the consumer base, has potential to shift the industrialized norm in the restaurant business. 


\section{References}

1. Dixon J. 1999. A cultural economy model for studying food systems. Agriculture and Human Values 16(2): 151-160.

2. Lockie S. 2002. 'The invisible mout': Mobilizing 'the consumer' in food productionconsumption networks. Sociologia Ruralis 42(4): 278-294.

3. Brown C, Stacy M. 2008. The Impacts of Local Markets: A Review of Research on Farmers Markets and Community Supported Agriculture. American Journal of Agricultural Economics 90(5): 1298-1302.

4. United States Department of Agriculture Agricultural Marketing Service. 2012. Farmers Markets and Local Food Marketing. Available at: http://www.ams.usda.gov/AMSv1.0/ams.fetchTemplateData.do?template=TemplateS\&le $\underline{\mathrm{ftNav}}=$ WholesaleandFarmersMarkets\&page $=$ WFMFarmersMarketGrowth\&description $=$ Farmers\%20Market\%20Growth\&acct=frmrdirmkt. Accessed on May 20, 2012.

5. Kingsolver B, Kingsolver C, and Hopp S. 2007. Animal, Vegetable, Miracle. New York, NY: Harper Collins.

6. Pollan M. 2007. Omnivore's Dilemma: A Natural History of Four Meals. New York, NY: Penguin.

7. APHA Policy Statement. 2007. Toward a Healthy, Sustainable Food System. Available at: http://www.apha.org/advocacy/policy/policysearch/default.htm?id=1361. Accessed on May 14, 2012.

8. Gold M. 2007. Sustainable Agriculture: Definitions and Terms. United States Department of Agriculture. 
9. National Restaurant Association. 2012. Chef Survey: What's Hot in 2012. Available at: http://www.restaurant.org/pressroom/social-mediareleases/images/whatshot2012/What's_Hot_2012.pdf. Accessed on May 14, 2012.

10. Guthrie JF, Lin B-H, and Frazao E. 2002. Role of food prepared away from home in the American diet, 1977-78 versus 1994-96: Changes and Consequences. Journal of Nutrition Education and Behavior 34(3): 140-150.

11. Tagtow A. 2009. Shades of Green Checklist. In: Healthy land, healthy food \& healthy eaters. American Dietetic Association Position Paper.

12. Byker C, Shanks J, Misyak S, and Serrano E. 2012. Characterizing Farmers Market Shoppers: A Literature Review. Journal of Hunger and Environmental Nutrition 7(1): $38-52$.

13. Nation's Restaurant News. 2008. Top 100: Part One of a Two-Part Report. Available at: http://www.nrn.com/uploadedFiles/Files/PDF/NRN_6-30-08_SR1.pdf. Accessed on May $15,2012$.

14. Nation's Restaurant News. 2011. Top 100. Available at: https://www.buypenton.com/ProductDetail.aspx?ID=NRNT100. Accessed on May 15, 2012.

15. French SA, Harnack L, and Jeffery RW. 2000. Fast food restaurant use among women in the Pound of Prevention study: dietary, behavioral and demographic correlates. International Journal of Obesity 24(10): 1353-1359.

16. Sorkin DH, Billimek J. 2012. Dietary Behaviors of a Racially and Ethnically Diverse Sample of Overweight and Obese Californians. Health Education \& Behavior, Epub ahead of print. 
17. United States Department of Agriculture Economic Research Service. 2012. Fast food is the single largest source of eating-out calories for U.S. adults and children. Available at: http://www.ers.usda.gov/data-products/chartgallery/detail.aspx?chartId=29852\&ref=collection. Accessed on May 20, 2012.

18. Rogers EM. 2003. Diffusion Networks. In Diffusion of Innovations (5th ed) (pp. 381 - 387). New York: Free Press.

19. Tobler C, Visschers VHM, and Siegrist M. 2011. Eating green. Consumers' willingness to adopt ecological food consumption behaviors. Appetite 57(3): 674-682.

20. Chipotle. F.W.I. Story. Available at: http://www.chipotle.com/\#/flash/fwi_story. Accessed on May 20, 2012.

21. Rolls BJ, Roe LS, and Meengs JS. 2006. Reductions in portion size and energy density of foods are additive and lead to sustained decreases in energy intake. The American Journal of Clinical Nutrition 83(1): 11-17.

22. Wallop H. McDonald's Goes McOrganic. The Telegraph. June 27, 2007

23. McDonald's Spain 2012. Sostenibilidad en la Cadena de Sumistro (Sustainability in the Supply Chain). Available at: http://www.mcdonalds.es/empresa/sostenibilidad-cadenasuministro. Accessed on May 20, 2012.

24. Porter ME, Kramer MR. 2006. Strategy and society: the link between competitive advantage and corporate social responsibility. Harvard business review 84(12): 78-92.

25. Dahl R. 2010. Green Washing: Do You Know What You're Buying? Environmental Health Perspectivs 118(6): A246-A252. 
Table. Top 20 Restaurants Sustainable Food Practices and Suggested Practices, 2008 and 2011

\begin{tabular}{|c|c|c|c|c|c|c|c|c|c|c|}
\hline \multirow{2}{*}{ Practice } & \multicolumn{10}{|c|}{ Top Restaurants 1 - 10} \\
\hline & McDonalds & Subway & $\begin{array}{c}\text { Burger } \\
\text { King }\end{array}$ & Starbucks & Wendy's & $\begin{array}{c}\text { Taco } \\
\text { Bell }\end{array}$ & $\begin{array}{l}\text { Dunkin } \\
\text { Donuts }\end{array}$ & $\begin{array}{c}\text { Pizza } \\
\text { Hut }\end{array}$ & KFC & Applebees \\
\hline $\begin{array}{l}\text { The producer } \\
\text { or farmer who } \\
\text { grew the food } \\
\text { is known }\end{array}$ & $\mathrm{p}$ & - & - & - & - & - & - & - & - & - \\
\hline $\begin{array}{l}\text { Traceable Food } \\
\text { Supply chain } \\
\text { (i.e. food } \\
\text { safety, } \\
\text { HACCP) }\end{array}$ & $p \mathrm{P}$ & - & - & $p$ & - & $p$ & - & $p$ & $p$ & - \\
\hline Local food & $\mathrm{p}$ & - & - & - & - & - & - & - & - & - \\
\hline $\begin{array}{l}\text { Food procured } \\
\text { within the } \\
\text { United States }\end{array}$ & - & $P$ & - & - & - & - & - & - & - & - \\
\hline Sustainable & - & $\mathrm{p}$ & - & $\mathrm{P}$ & - & - & - & - & - & - \\
\hline Natural & - & - & - & - & - & - & - & $\mathrm{p}$ & - & - \\
\hline Organic & - & - & - & - & - & - & - & - & - & - \\
\hline
\end{tabular}


Chain Restaurant Sustainable Practices

\begin{tabular}{|c|c|c|c|c|c|c|c|c|c|c|}
\hline Cage Free & - & - & $P \mathrm{P}$ & - & $\mathrm{P}$ & - & - & - & - & - \\
\hline Non-Confined & $\mathrm{p}$ & - & - & - & $\mathrm{p}$ & - & . & - & - & - \\
\hline $\begin{array}{l}\text { Antibiotic/ } \\
\text { Hormone-Free }\end{array}$ & & $P \mathrm{P}$ & & & $\mathrm{P}$ & - & . & - & - & - \\
\hline $\begin{array}{l}\text { Sustainable } \\
\text { Fish }\end{array}$ & $\mathrm{P}$ & $\mathrm{P}$ & - & - & - & - & - & - & - & - \\
\hline $\begin{array}{l}\text { Animal } \\
\text { Welfare } \\
\text { Approved }\end{array}$ & - & - & $p$ & - & $p$ & - & - & - & $p$ & - \\
\hline Fair Trade & $\mathrm{P}$ & - & - & $\mathrm{P}$ & - & - & & - & - & - \\
\hline $\begin{array}{l}\text { Nutrition } \\
\text { Labeling }\end{array}$ & $\mathrm{p}$ & $P$ & $P$ & - & - & - & & . & - & - \\
\hline $\begin{array}{l}\text { Non-profit pay } \\
\text { what you want }\end{array}$ & - & - & - & - & - & - & & . & - & - \\
\hline
\end{tabular}


Chain Restaurant Sustainable Practices

\begin{tabular}{|c|c|c|c|c|c|c|c|c|c|c|c|c|}
\hline \multirow{2}{*}{ Practice } & \multicolumn{10}{|c|}{ Top Restaurants 11 - 20} & \multicolumn{2}{|c|}{$\begin{array}{l}2008 \text { Restaurants not } \\
\text { included in } 2011\end{array}$} \\
\hline & Chilis & Sonic & $\begin{array}{l}\text { Chick-fil- } \\
\text { A }\end{array}$ & $\begin{array}{l}\text { Olive } \\
\text { Garden }\end{array}$ & Dominos & $\begin{array}{c}\text { Jack in the } \\
\text { Box }\end{array}$ & $\begin{array}{c}\text { Panera } \\
\text { Bread }\end{array}$ & Arby's & $\begin{array}{l}\text { Dairy } \\
\text { Queen }\end{array}$ & $\begin{array}{c}\text { International } \\
\text { House of } \\
\text { Pancakes }\end{array}$ & $\begin{array}{c}\text { Outback } \\
\text { Steak } \\
\text { House }\end{array}$ & $\begin{array}{c}\text { Red } \\
\text { Lobster }\end{array}$ \\
\hline $\begin{array}{l}\text { The producer } \\
\text { or farmer who } \\
\text { grew the food } \\
\text { is known }\end{array}$ & - & - & - & - & - & - & - & - & - & - & - & - \\
\hline $\begin{array}{l}\text { Traceable Food } \\
\text { Supply chain } \\
\text { (i.e. food } \\
\text { safety, } \\
\text { HACCP) }\end{array}$ & - & - & - & - & - & $P$ & - & - & - & - & - & - \\
\hline Local food & - & - & - & - & - & - & - & - & - & - & - & - \\
\hline $\begin{array}{l}\text { Food procured } \\
\text { within the } \\
\text { United States }\end{array}$ & - & - & - & - & - & - & - & - & - & - & - & - \\
\hline Sustainable & - & - & $\mathrm{p}$ & - & - & - & - & - & - & - & - & - \\
\hline Natural & - & - & - & - & - & - & - & - & - & - & - & - \\
\hline Organic & - & - & - & - & - & - & $\mathrm{p}$ & - & - & - & - & - \\
\hline Cage Free & - & $P$ & - & - & - & - & - & - & - & - & - & - \\
\hline
\end{tabular}


Chain Restaurant Sustainable Practices

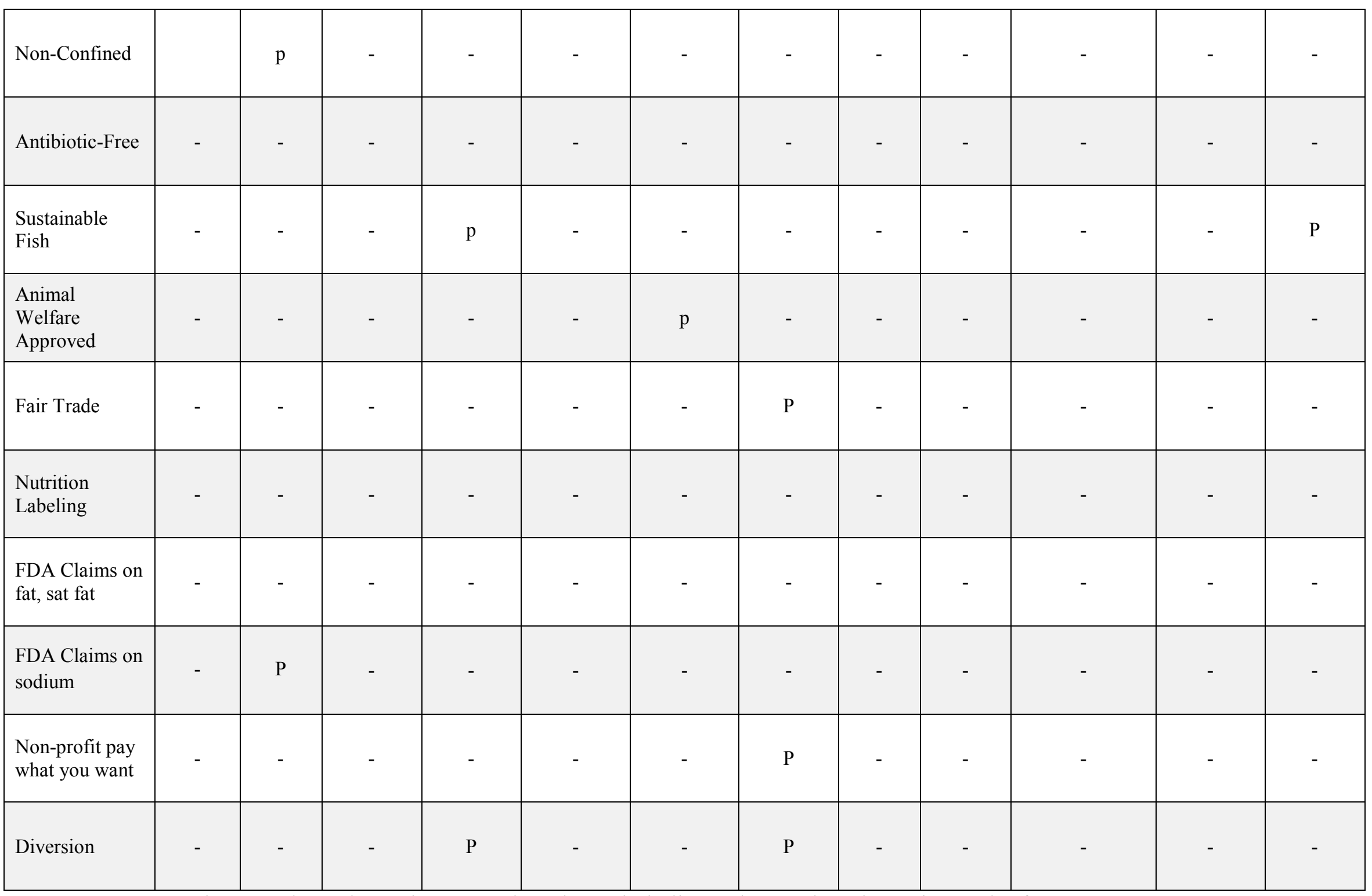

Note. $\mathrm{P}=$ Practice; $\mathrm{p}=$ Planned Practice; 2008 data shown in italics and 2011 data shown in regular font. 